\title{
Food security in rural areas of Limpopo province, South Africa
}

\author{
N. De Cock • M. D'Haese • N. Vink • C. J. van Rooyen • \\ L. Staelens • H. C. Schönfeldt • L. D'Haese
}

Received: 1 November 2012 / Accepted: 24 January 2013 / Published online: 15 February 2013

(C) The Author(s) 2013. This article is published with open access at Springerlink.com

\begin{abstract}
Although South Africa is food secure as a nation, many households remain food insecure. The government has recognized several key food security challenges in the Integrated Food Security Strategy (IFSS). However, South Africa still lacks specific and accepted methods to measure food security and currently has no regulated way of monitoring the food security status of its population. This article reports on an investigation into the food security situation of rural households in the Limpopo Province. Qualitative and quantitative data were gathered across five districts in the province. The study sample eventually involved 599 households in the rural areas of Limpopo. This allowed a thorough description of household characteristics and livelihoods and an assessment of the food security and poverty levels in the area. The findings showed that $53 \%$ of the sampled rural households declared themselves to be severely food insecure. Multivariate analyses were used to identify the main household characteristics that determined the household's
\end{abstract}

We would like to thank and acknowledge Stellenbosch University Food Security Initiative HOPE project for funding that enabled the research to be undertaken.

N. De Cock $\cdot$ M. D’Haese $\cdot$ L. Staelens

Department of Agricultural Economics, Ghent University,

Coupure links, 653,

9000 Ghent, Belgium

N. Vink $(\bowtie) \cdot$ C. J. van Rooyen

Department of Agricultural Economics,

University of Stellenbosch, Private Bag X1,

Matieland 7602, South Africa

e-mail: nv@sun.ac.za

H. C. Schönfeldt

University of Pretoria, Private Bag X20, Hatfield,

Pretoria 0028, South Africa

L. D'Haese

University of Antwerpen, Groenenborgerlaan 171,

2020 Antwerpen, Belgium food security status. These determinants were mainly human capital (education, household size and dependency ratio), household income and district in which the households were situated. The findings indicated that policy priorities should be focused on the promotion of rural education and creating an enabling environment for the rural labour market.

Keywords Food security $\cdot$ Rural poverty $\cdot$ South Africa

\section{Introduction}

The government of South Africa has committed to halving poverty between 2004 and 2014. In order to achieve this objective it is crucial to achieve household food security. Therefore the government adopted the Integrated Food Security Strategy (IFSS) in 2002. The vision is: "to attain universal physical, social and economic access to sufficient, safe and nutritious food by all South Africans at all times to meet their dietary and food preferences for an active and healthy life" (IFSS 2002: 13). This vision is similar to the definition of food security of the FAO. The goals of the IFSS are linked to the millennium development goals (MDGs), especially MDG 1 ("to reduce hunger, malnutrition and food insecurity by half by 2015.") The IFSS was subsequently translated into the "Integrated food security and nutrition program" (IFSNP), which has a task team in the National Department of Agriculture, Forestry and Fisheries (DAFF) to oversee its implementation (Jacobs 2009). Next to the IFSS, the South African government has recently started two other programmes to increase food security within its population. First, the Zero Hunger Programme of DAFF focuses on food access, food production, nutrition security, development of marketing channels, fostering of partnerships with relevant stakeholders and promoting stakeholder dialogue (Zita 2012). Second, the Outcome 7 programme launched by the government focuses on sustainable agrarian reform and aims to improve access to 
affordable and diverse food, rural services and sustainable livelihoods, rural job creation and enabling an institutional environment for sustainable and inclusive growth (Governement of South Africa 2010). Outcome 7 is a broader development programme while zero hunger focuses on reducing hunger.

While South Africa is food secure at a national level, ${ }^{1}$ the available data suggests that this is not the case for all households. Yet, the South African poverty context is particular, given the high inequality in income and asset ownership. Hence the effect of policy measures towards reducing poverty and food insecurity, and establishing the link between poverty, incomes and food security is still unclear in areas that were disadvantaged during the apartheid era, making policy targeting difficult.

Food security is multidimensional in nature and that makes accurate measurement and policy targeting quite challenging. In South Africa various methods to assess food security at household level have been used. These include the National Food Consumption Survey (NFCS), Food Insecurity and Vulnerability information and Mapping System (FIVIMS), General Household Survey (GHS), the Income and Expenditure Survey (IES), Community Survey (CS), South African Social Attitudes Survey (SASAS) and Labour Force Survey (LFS), to name the most important (see, Labadarios et al. 2009). Each of these studies obtained different results: the 1995 IES indicated that around $43 \%$ of households (rural and urban) were food insecure while the NFCS of 2005 showed that $52 \%$ of households were experiencing hunger. On the other hand, the GHS of 2007 estimated that $10.6 \%$ and $12.2 \%$ of adults and children, respectively, were sometimes or always hungry (Jacobs 2009). Aliber (2009) mentions that according to the GHS only up to $1.3 \%$ of the households in the Limpopo province often or always experienced hunger. Several authors (e.g. Hart 2009; Altman et al. 2009; Jacobs 2009; Baiphethi 2009) point out that this variation in the results obtained is because each survey probes a different dimension of food security (food expenditure, hunger and household food production) thereby using different indicators/measures.

In trying to get a better insight into the level of rural food insecurity, a research project was launched to provide an indepth comprehension of the social and economic aspects of food security at household levels in the Limpopo province. This paper reports on the results and explores the food security level among members of households interviewed in five districts of the Province. Different indicators of food security were compared, and the major determinants of food insecurity are described. For the purposes of this research, the definition of food security is based on the FAO's definition: "a situation

\footnotetext{
${ }^{1}$ For example, The Economist Intelligence Unit's new Global Food Security Index ranks South Africa $40^{\text {th }}$ most food secure out of the 105 countries that were measured (EIU 2012).
}

that exists when all people, at all times, have physical, social, and economic access to sufficient, safe, and nutritious food that meets their dietary needs and food preferences for an active and healthy life". This definition comprises four key dimensions of food supplies: availability, stability, accessibility, and utilization. A food system is vulnerable when one or more of the four components of food security are uncertain and insecure (FAO 2008).

\section{Materials and methods}

By mid-2011, the population in Limpopo province was approximately 5.55 million people, or $10 \%$ of South Africa's total population (SSA 2008). About $90 \%$ of the population of the province lives in rural areas and $47.5 \%$ is younger than 15 years old. Limpopo province had the highest population growth in the country of $3.9 \%$ per annum.

A two-stage stratified approach with quota sampling was used to collect data among households in July/August 2011. From each of the five municipal districts of the Province, two municipalities were selected, based on cost and the location of the municipality (see Table 1). Within each municipality 60 households were surveyed, totalling 600 households (one household was dropped from the analysis). In order to ensure that the sample within each municipality was representative, the enumerators first met at one central point in the village. From there, a random direction was chosen for each enumerator, and then households were selected between the central point and the end of the village. It should be noted that the sample size in each district is independent of the size of the district. Hence representativeness at district level was not controlled.

From the data collected, the following frequently used food security indicators were computed to assess the food security status of the households:

- The Household Food Insecurity Access Scale (HFIAS) was developed by the Food and Nutrition Technical Assistance (FANTA) project of US-AID. The FANTA Household Food Insecurity Access Scale consists of asking respondents to answer nine questions which represent universal domains of the experience of insecure access to food (Deitchler et al. 2010). The nine questions probe whether or not the household experienced one form of insufficient access to food in the past 4 weeks, and if yes, with what frequency. Based on these 9 questions two indicators can be computed. The HFIAS score is a continuous measure of the degree of food (access) insecurity, where households have three possible responses to each of the nine questions, i.e. it ranges from 0 to 27; the higher the score, the greater the food (access) insecurity the household experienced. Secondly, the Household Food Insecurity Access Prevalence 
Table 1 Districts and their municipalities covered in this research

${ }^{\mathrm{a}}$ Selected municipalities

\begin{tabular}{|c|c|c|c|c|}
\hline Capricorn District & Mopani District & Sekhukhune District & Vhembe District & Waterberg District \\
\hline Aganang & Baphalaborwa & Grobersdal & Makhado & Bela-Bela \\
\hline Blouberg $^{\mathrm{a}}$ & Giyani $^{\mathrm{a}}$ & Fetakgomo $^{\mathrm{a}}$ & Mutale $^{\mathrm{a}}$ & Mogalakwena $^{\mathrm{a}}$ \\
\hline Lepelle & Letaba & Makhuduthamaga & Musina & Modimolle \\
\hline Molemole $^{\mathrm{a}}$ & Maruleng ${ }^{\mathrm{a}}$ & Tubatse $^{\mathrm{a}}$ & Thulamela $^{\mathrm{a}}$ & Mookgopong ${ }^{\mathrm{a}}$ \\
\hline Nkumpi & Tzaneen & Marble Hall & & Thabazimbi \\
\hline Polokwane & & & & Lephalale \\
\hline
\end{tabular}

(HFIAP) categorizes households into four levels of household food insecurity: food secure, and mildly, moderately and severely food insecure. Households are categorized as increasingly food insecure as they respond affirmatively to more severe conditions and/or experience those conditions more frequently (Coates et al. 2007).

- The Household Dietary Diversity Score (HDDS) reflects the number of different food groups consumed by the household. The respondents were asked whether or not any household member consumed a food item pertaining to one of the nine predefined food groups at least once in the last 7 days. This included consumption of the food item at home or home-prepared but consumed outside the home. The number of affirmative answers was summed. The nine food groups are (Labadarios et al. 2011): cereals and tubers, vitamin A rich vegetables and fruit, other vegetables and fruit, legumes, meat and fish, eggs, dairy, oil and fat, sugar, and beverages. These food groups should reflect the combination of nutritional needs for a healthy diet. The HDDS ranges between 0 and 9. Alternative scales of HDDS consider up to 12 food groups (e.g. FANTA guidelines).

- The Months of Adequate Household Food Provisioning (MAHFP) measures how many months of the past year a household was not able to provide itself with enough food. The household respondents were asked which months of the past twelve the household did not have access to sufficient food to meet their household needs. A MAHFP score was calculated which ranges from 0 to 12 (Swindale and Bilinsky 2007).

- While it is not a direct measure of food insecurity, share of food in the total household expenditure was calculated (Leroy et al. 2001). Food expenditure was computed by summing the expenditure on all individual food items bought in 1 month. A relative high share of income spent on food is often linked to poor households (Engel's law). Yet, it is worthwhile mentioning that expenditure on food will depend on many other parameters including change in food prices and location (availability of shops).

- A household is defined as having Low Energy Availability (LEA) when the energy available by the household's food supplies is less than the sum of recommended energy intakes for each member. The numerator of the LEA calculation is the sum of the energy available in the food purchases reported by the household plus the energy consumed from food produced at home during 1 month. The denominator is a sum of the daily recommended energy intakes for each member of the household, multiplied by thirty to convert it to the same monthly time frame as the numerator. Households that scored $<1$ on this ratio were defined as having low energy availability (Rose and Charlton 2002).

- A household is said to be in Food Poverty (FP) when the amount of money it spends on food is not enough to purchase a basic diet that is nutritionally adequate. This is reflected in the ratio of household food spending to the cost of a basic food basket. The latter was calculated based on the NAMC food basket (NAMC 2011), which comes down to the cost for $2139.38 \mathrm{kcal}$ per person per day which is $408 \mathrm{R} /$ person/month. The numerator of this ratio is the sum of a household's reported food expenditure plus the estimated monetary value of the food that it consumed from home production. The denominator is the cost of a nutritionally adequate food basket for a particular household (Rose and Charlton 2002)

The food security indicators in this paper measure food access and to a lesser extend food availability, quality and safety. Sustainability issues are partly captured in the MAHFP index. To measure food utilisation, a 24-hour or 7 day recall of food consumption could be more appropriate. Yet, mistakes or mis-measurement due to inability to recall exactly what was consumed, could lead to important biases. Furthermore, the survey should pertain to individual daily consumption including accounting for portion sizes and meal frequency. Hence, it was decided not to include a 24hour recall of food consumed in the household because it would introduce a substantial measurement bias while taking much of the respondents' time and concentration. Similarly, households were not asked to keep a 7-day food consumption diary because of logistics and the low level use of scales.

Apart from the survey, focus group discussions were held. Secondary data that pertain to the five districts of the province and two municipalities per district were collected. 
Socio-economic data covering the ten municipalities were obtained from the South African Statistical Services (StatsSA). Variables on the agricultural sector came from the Agricultural Census of 2004.

\section{Results}

\section{Demographic characteristics}

On average, a household is composed of 6.5 household members with a standard deviation (SD) of 3.0. There were no significant differences between the household sizes of the different districts and municipalities. The average age of the household head for Limpopo province was 56.1 (SD 15.7) years old, while the general population is considerably younger.

In Limpopo province, men head $60.5 \%$ of the households and women $39.5 \%$. Furthermore, household heads have a generally low level of education. Some $32.4 \%$ have had no schooling, although most of the household heads have either completed junior primary or senior primary or have had some secondary education. The low levels of education are skewed towards the older generation, as they grew up in the apartheid era and had limited access to formal education.

Two different types of dependency ratios were computed. Firstly, the number of potentially active persons (people between 18 and 65 years old) was divided by the total household size. This results in an 'independency ratio' that reflects the potential for households to gain income and be economically active. In the sample, the average ratio was 0.84 , so $84 \%$ of the household members could potentially be contributing to household income. Secondly the dependency ratio reflects how many household members were supporting the whole household. On average, each economically active person in the sampled households supported 5.16 household members who were either too young or too old to work, or who could not find employment.

Almost all the surveyed households $(99.8 \%)$ were black African households. The average number of years that people had been living in the area was 32 , which shows high stability, as opposed to the constant transition of informal communities. Programmes implemented by the Limpopo government would therefore directly impact on local communities over time and could become part of their "institutional memory" - a good motivation for change agents to invest in such communities.

Most of the people in the province used piped water for drinking and cooking, which came from a tap in the yard (36\%) or from a public kiosk (33\%). The rest of the households used water from sources such as a water carrier or tanker, rainwater tanks, rivers, dams, wells or springs. In terms of sanitation, $95 \%$ of the people use some form of a toilet facility, with the three main types used being pit latrine (48.9\%), improved ventilated pit latrine $(38.7 \%)$ and flush toilets $(6.7 \%)$.

When households were asked if they were connected to the electricity supply, $92 \%$ indicated yes. Beyond this, about $64 \%$ of the households used wood and $28 \%$ of the households used electricity from the grid for cooking and boiling. A small percentage of the households ( $8 \%$ ) used other sources of energy including dung, electricity from a generator, charcoal, gas and/or paraffin oil for cooking and boiling water. On average $89 \%$ of the households use electricity from the grid for lighting, while only a small proportion of the households use other sources of energy for lighting (candles $4 \%$, wood $3 \%$, paraffin oil $1 \%$ and electricity from a generator $1 \%$ ).

Household food availability, consumption and dietary diversity

The choice of HFIAS score in the survey was inspired by many other studies such as those of Coates et al. 2006, 2007; Frongillo and Nanama 2006; Melgar-Quinonez et al. 2006; Swindale and Bilinsky 2006; and Webb et al. 2006. Furthermore, it has been used in South Africa in the following recent studies: Ballantine et al. 2008; Faber et al. 2009; Kirkland et al. 2011; Oketch et al. 2011; Taylor et al. 2011; and Hendriks 2005. According to the HFIAS methodology $14.8 \%$ of the people in the sample were food secure, $5.8 \%$ were mildly food insecure, $26.4 \%$ were moderately food insecure and $53.1 \%$ were severely food insecure (Table 2). The largest share of food secure households was in Sekhukhune, while the largest share of food insecure households was in Waterberg. Maruleng, a municipality in Mopani district, also had a high number of severely food insecure households (65\%). The Mopani district came out as the poorest district when average income levels were compared. It also had the highest share of households living below the poverty line of R502 per person per month (Gumede 2010).

For those households that experienced hunger, the period ranged between 1 and 4 months, with the greatest number of households experiencing one $(13.2 \%)$ or two $(10.2 \%)$ months of hunger. On a district level, Waterberg presents the highest average number of months (3.1) when people faced hunger. Conversely, Mopani district experienced the lowest number of hungry months (less than 1 month). January was the month in which the largest number of households (25.9\%) experienced hunger followed by June (17.2\%), February (16.2\%), July (15.5\%) and December (15.2\%).

A report on a survey in Sekhukhune (Rule et al. 2005) confirmed that most of the households experienced a lack of food or money during January and February. There are a number of factors that could explain this food shortage: 
Table 2 HFIAS Categories by district and by municipality in Limpopo province

\begin{tabular}{llcccc}
\hline District & Municipality & Food secure & $\begin{array}{l}\text { Mildly food } \\
\text { insecure }\end{array}$ & $\begin{array}{l}\text { Moderately food } \\
\text { insecure }\end{array}$ & $\begin{array}{l}\text { Severely food } \\
\text { insecure }\end{array}$ \\
\hline \multirow{3}{*}{ Capricorn } & $\%$ & & & & \\
& Blouberg & 9.1 & 1.5 & 27.3 & 62.1 \\
\multirow{3}{*}{ Mopani } & Molemole & 13.5 & 5.8 & 21.2 & 59.6 \\
& Giyani & 8.2 & 6.6 & 23.0 & 62.3 \\
\multirow{3}{*}{ Sekhukhune } & Maruleng & 6.7 & 3.3 & 25.0 & 65.0 \\
\multirow{3}{*}{ Vhembe } & Fetakgomo & 29.3 & 13.8 & 31.0 & 25.9 \\
& Tubatse & 18.6 & 11.9 & 37.3 & 32.2 \\
\multirow{2}{*}{ Waterberg } & Mutale & 13.3 & 5.0 & 40.0 & 41.7 \\
& Thulamela & 20.7 & 3.4 & 25.9 & 50.0 \\
\multirow{2}{*}{ Overall } & Mookgopong & 10.3 & 1.7 & 20.7 & 67.2 \\
\hline
\end{tabular}

- A household budget deficit caused by high spending patterns over the festive season.

- A lack of income during the festive season due to vacation leave.

- Funds being allocated to other cost items (e.g. school fees and uniforms) in January.

Households had an average HDDS of 4.5 out of the nine food groups. Maize products had the highest frequency with a mean consumption of 6.7 in 7 days, largely because maize products are the staple food of the province, while pork (for religious reasons) and venison (high cost) were the least consumed. These data on the frequency of consumption were supported by data on the allocation of household food budgets. Most money was spent on maize products (R205.80 per month) $)^{2}$ followed by other cereal products such as bread with a monthly expenditure of R118.70 per month and poultry with R117.20 per month. Food groups with the lowest average expenditure per month included venison or wild game (R2.30 per month), followed by pork (R3.92 per month) and edible insects (R6.35). Mopani worms were among the least bought and consumed as consumption is seasonal.

These data support the findings of the NFCS (2005) in that most households purchased most of their food, and farming, whether subsistence or commercial, was not a major source of the most widely consumed food items, including the staple, maize (Rule et al. 2005; NFCS-FB-I 2008)

Information was also gathered on intra-household food distribution during instances of food shortages to find out whether this affected food distribution within the household. Forty-eight per cent of the respondents indicated that female adults (18 years and above) would be the ones eating less

\footnotetext{
${ }^{2}$ In 2011 the exchange rate was approximately US\$1=ZAR7.50
}

when confronted with a food shortage, which makes them the most vulnerable group to food insecurity. Children under 5 years were the most likely to have adequate food to eat, followed by older children ( $5-18$ years). Most adults ate on average two or three times a day, with $54.6 \%$ of the household having two meals and $35.4 \%$ having 3 meals a day.

\section{Household food production}

It is difficult to assess the true contribution of own food production as households did not report or recall crop production in their back yards but 273 households reported having arable land with an average of 2.35 ha (SD 3.43). The survey also confirmed that 1) communal land is the most common type of land tenure; and 2) livestock is kept on communal grazing land.

Some $57 \%$ of the sampled households are involved in crop production, with maize the most frequently grown (31\% of households), followed by mangos ( $24.2 \%$ ), spinach $(15.4 \%)$, pawpaws $(15.4 \%)$ and tomatoes (14.2\%). The average output at the household level in the previous year was largest for tomatoes ( $305 \mathrm{~kg}$ ) followed by mangos $(212 \mathrm{~kg})$, maize $(170 \mathrm{~kg})$, cabbage $(117 \mathrm{~kg})$ and avocados $(21 \mathrm{~kg})$. All crops displayed a large average subsistence ratio (amount of production consumed/total production). The subsistence ratios tended to be largest for fruit $(87 \%)$, followed by staple crops ( $55 \%$ ) and vegetables $(54 \%)$. This indicates that in general people tend to produce fruit mainly for their own consumption, while for staple crops and vegetables, households consume half of the production and the other half is sold. Foods harvested from the wild were not captured by the survey. They may add to the numbers of own production (see Modi et al. 2006).

When considering marketing, the most important crops are mango ( $8.9 \%$ of households involved in marketing), 
tomato $(7.7 \%)$, spinach $(7.7 \%)$, other leafy vegetable $(4.7 \%)$, maize $(4.5 \%)$ and cabbage $(4.4 \%)$. These crops are usually sold in local informal markets, at farm gate or along the road.

The most important livestock owned by most households in the province by animal numbers are poultry, goats, cattle and pigs. More than $30 \%$ of the households own poultry and about $43 \%$ possess goats or cattle while fewer than $8 \%$ own pigs, sheep or fish. At the district level, $68.3 \%$ of households in Vhembe own some livestock, in contrast with only $21 \%$ in Waterberg.

Households that own poultry own on average 16 animals, while households that own cattle own on average 11 head, and households that own goats own on average 10 goats. This indicates that livestock production is an investment choice that the household makes. The average selling price of cattle is about R3,450, of goats R714, sheep R700 and pigs R412. The average selling price of poultry is around $\mathrm{R} 25$.

Household income level

On average, a household in the selected sample has an income of R2,953 per month (SD: R4121). Of all the households, $7.6 \%$ indicated that they had an income of less than R500 per month and $7.6 \%$ had an income of more than R7,500. At a district level, Mopani had the lowest income as almost $20 \%$ of the households received less than R500 per month. Households in the districts of Sekhukhune and Vhembe were generally better off, as $43.4 \%$ in both reported incomes greater than R3,000 per month.

When households were asked to identify their principal sources of monthly income, $75 \%$ indicated that they received social grants from the State, ${ }^{3}$ while $31 \%$ receive some kind of formal salary. Farming income and remittances were income sources for $15 \%$ and $13 \%$ of households, respectively. Social grants were, thus, the most prevalent source of income across all districts.

A formal salary was the main income source for $26.2 \%$ of the households in the sample. At district level, Sekhukhune had the highest percentage $(43.7 \%)$ of households receiving a formal salary as a main income source, whereas Mopani had the lowest (22.3\%). Further, $43 \%$ of Limpopo households had members who had migrated for work or to find employment. Of all migrants, only $25.5 \%$ sent money to their household of origin. Sekhukhune district had the highest proportion (28.6\%) of migrants sending remittances, whereas Capricorn had the lowest (23\%). On average, households received R1,183.31 per month as remittances, mainly through deposits into their bank accounts. In

\footnotetext{
$\overline{3}$ These consist mostly of old age pensions, child support grants, disability grants and veteran grants.
}

Limpopo province, $5 \%$ of households reported that remittances were the most important source of household income. This has significantly decreased from $20.8 \%$ observed during the S.A. general household survey (StatsSA 2009).

Next to income related questions, respondents were also asked if they had some kind of financial assets. The three most important financial services in which households were involved were: burial insurance (55.8\%), savings at a bank/post office (42.2\%) and membership of a burial society $(26.4 \%)$. The difference between burial insurance and a burial society is that burial insurance is a formal policy that can be taken out as a contract between the insurer and a formal financial institution such as a bank or insurance company with terms that are specifically designed to ensure that the earnings be used only to pay the burial expenses of only the insured. A burial society is regarded as an informal financial policy in the form of a rotating savings and credit scheme, which is usually formed by people from the same community to cover the costs of burying members (DGRV 2003).

\section{Food security indicators}

Data for six food security indicators with their means, standard deviations and maxima are given in Table 3. In the Limpopo province, the average HFIAS score was 10.05 (the higher the score, the more food insecure). The mean HDDS was 4.57 , i.e. a household consumption per month of just under half of the different food groups available to them, a result which is consistent with the one found by Aliber (2009). Households were able to provide themselves with adequate food for 10.28 months on average. The average LEA of households in Limpopo province was 0.57 and the average FP was 1.15. Of the 599 households, 437 had an $\mathrm{FP}<1$, meaning that their food expenditure is smaller than the price of an adequate food basket for

Table 3 Summary statistics of the 6 indicators

\begin{tabular}{lrcc}
\hline Indicator & Mean & $\begin{array}{c}\text { Standard } \\
\text { deviation }\end{array}$ & $\begin{array}{l}\text { Maximum value } \\
\text { recorded }\end{array}$ \\
\hline HFIAS $^{\mathrm{a}}$ & 10.05 & 6.83 & 27.00 \\
HDDS $^{\mathrm{b}}$ & 4.57 & 1.96 & 9.00 \\
MAHFP $^{\mathrm{c}}$ & 10.28 & 2.88 & 12.00 \\
Food/HH expenditure $^{\mathrm{L}}$ & 0.63 & 0.26 & 1.00 \\
LEA $^{\mathrm{d}}$ & 0.57 & 0.68 & 14.18 \\
FP $^{\mathrm{e}}$ & 1.15 & 3.41 & 63.43 \\
\hline
\end{tabular}

${ }^{\mathrm{a}}$ Household Food Insecurity Access Score

${ }^{\mathrm{b}}$ Household Dietary Diversity Score

${ }^{\mathrm{c}}$ Months of Adequate Household Food Provisioning

${ }^{\mathrm{d}}$ Low Energy Availability

${ }^{\mathrm{e}}$ Food Poverty 
all household members. Also, 538 households had an LEA $<1$, indicating that $90 \%$ of the households have an energy intake below their energy requirements.

The nine questions of the Household Food Insecurity Access Prevalence (HFIAP) assist in the categorisation of households into four levels of food insecurity, namely food secure, mildly food insecure, moderately food insecure and severely food insecure (see Coates et al. (2007) for details). Based on the FP and the LEA indicators, a classification of the households into four food security categories can be made (called the Rose and Charlton scale). These are food secure, only low energy availability (LEA), only food poor (FP) and food insecure.

According to the HFIAP, $53 \%$ of the households were severely food insecure, $26 \%$ were moderately food insecure, $6 \%$ were mildly food insecure and $15 \%$ were considered as food secure. In contrast, the Rose and Charlton scale categorized $71.1 \%$ as food insecure and $8.3 \%$ as food secure: $18.7 \%$ of the household had only low energy availability and $1.8 \%$ were only food poor. The large difference in the number of households categorized as food insecure by the two scales is explained by the difference in food security indicators used. The Rose and Charlton scale is based on the LEA and FP indicators that score energy intake of the household and expenditure on food, respectively and is computed using approximations (such as household energy requirements, price of an adequate food basket, energy value of food groups), whereas the HFIAS scale is based on a score depending on the answer given to nine questions related to the perception of access to food.

Food security indicators in relation to household characteristics

In Table 4 the differences in indicator scores between male and female-headed households are given. On every indicator, female-headed households scored worse than maleheaded households, a result which is most probably reflects their lower socio-economic status. Food spending comprised a larger share of household expenditure for femaleheaded households. An independent $t$-test showed significant differences, except for LEA, between male and female headed households.

Table 5 shows the mean HFIAS, HDDS, MAHFP, food/HH expenditure, LEA and FP for different education levels of the household heads. Where the household head had a diploma or a degree the scores were best on each indicator: they have the lowest HFIAS, the highest HDDS, the highest MAHFP, the lowest food/HH expenditure, the highest LEA and the highest FP. Education leads to a better household food security status: probably the combined effect of better knowledge on nutrition and better access to food as a consequence of a higher income. A Tukey test was
Table 4 Food security indicators in relation to the gender of the household head

\begin{tabular}{lcrc}
\hline & \multicolumn{1}{l}{ Male } & \multicolumn{1}{l}{ Female } & \multicolumn{1}{l}{ t-stat } \\
\hline & Mean (stdev) & & \\
HFIAS $^{\text {a }}$ & $8.90(6.75)$ & $11.84(6.58)$ & $-5.257^{* * *}$ \\
HDDS $^{\mathrm{b}}$ & $4.73(2.03)$ & $4.33(1.83)$ & $2.472 * *$ \\
MAHFP $^{\mathrm{c}}$ & $10.50(2.06)$ & $9.93(3.25)$ & $2.260^{* *}$ \\
Food/HH expenditure $^{\text {LEA }}$ & $0.58(0.26)$ & $0.70(0.23)$ & $-5.949 * *$ \\
FEA $^{\mathrm{d}}$ & $0.58(0.82)$ & $0.55(0.36)$ & 0.496 \\
& $1.36(4.28)$ & $0.80(1.11)$ & $2.336^{* *}$
\end{tabular}

${ }^{\mathrm{a}}$ Household Food Insecurity Access Score

${ }^{\mathrm{b}}$ Household Dietary Diversity Score

${ }^{\mathrm{c}}$ Months of Adequate Household Food Provisioning

${ }^{\mathrm{d}}$ Low Energy Availability

${ }^{\mathrm{e}}$ Food Poverty

$* 10 \%$ significance level, $* * 5 \%$ significance level, $* * * 1 \%$ significance level.

also executed to see which groups differed significantly: mostly significant differences between the lower education and higher education levels were found.

Table 6 gives an overview of the average values of the household characteristics for the different food security categories. Households that were food secure tended to have low HFIAS scores, the highest monthly household income and the highest income per capita. These food secure households had an average household size of 5.61 and their household head had an average age of 57.63 years. These households all showed the lowest dependency ratio and the second lowest ratio of non-active over active household members: there were fewer people in the household that needed care. Although they had more land for growing crops, they did not have the highest energy intake from their own production. In addition, these households had the highest percentage of male-headed households, the lowest percentage of household heads without schooling and the highest percentage of household heads with certificates of formal training or had diplomas or degrees.

The severely food insecure households on the contrary had the highest HFIAS scores, the lowest monthly household income, the lowest income per capita, the highest household size and the lowest age of the household head. This is to be expected as food insecure household tend to have high household sizes, low income, have either a young or elderly household head and obtain a lot of their energy intake from their own production. Next to the age and the household size, the findings related to energy intake were also confirmed with the highest energy intake obtained from own production. However, they had the smallest area of land for growing crops $(0.88 \mathrm{ha})$ and only had 1.64 livestock units on average. The percentage of 
Table 5 Food security in relation to the education level of the household head

\begin{tabular}{lclllllll}
\hline & No schooling & $\begin{array}{l}\text { Junior } \\
\text { primary }\end{array}$ & $\begin{array}{l}\text { Senior } \\
\text { primary }\end{array}$ & $\begin{array}{l}\text { Some } \\
\text { secondary }\end{array}$ & $\begin{array}{l}\text { Completed } \\
\text { high school }\end{array}$ & $\begin{array}{l}\text { Courses or } \\
\text { certificates for } \\
\text { formal training }\end{array}$ & $\begin{array}{l}\text { Diploma or } \\
\text { degree }\end{array}$ & F-stat \\
& & & & & & & & \\
& Mean (standard deviation in brackets) & & & & \\
HFIAS $^{\mathrm{a}}$ & $11.58(6.31)^{\mathrm{a}}$ & $10.45(6.36)^{\mathrm{a}}$ & $11.00(7.54)^{\mathrm{a}}$ & $10.15(6.79)^{\mathrm{a}}$ & $8.25(6.02)^{\mathrm{a}, \mathrm{b}}$ & $4.75(6.36)^{\mathrm{b}, \mathrm{c}}$ & $2.59(3.90)^{\mathrm{c}}$ & $11.64 * * *$ \\
HDDS $^{\mathrm{b}}$ & $4.30(1.82)^{\mathrm{a}}$ & $4.24(1.95)^{\mathrm{a}}$ & $4.46(1.85)^{\mathrm{a}, \mathrm{b}}$ & $4.58(2.09)^{\mathrm{a}, \mathrm{b}}$ & $5.35(1.94)^{\mathrm{a}, \mathrm{b}}$ & $5.25(1.71)^{\mathrm{a}, \mathrm{b}}$ & $5.76(2.18)^{\mathrm{b}}$ & $5.15 * * *$ \\
MAHFP $^{\mathrm{c}}$ & $10.40(2.51)^{\mathrm{a}, \mathrm{b}}$ & $9.89(3.32)^{\mathrm{a}}$ & $9.91(2.99)^{\mathrm{a}}$ & $10.23(2.96)^{\mathrm{a}, \mathrm{b}}$ & $10.30(3.06)^{\mathrm{a}, \mathrm{b}}$ & $10.40(3.53)^{\mathrm{a}, \mathrm{b}}$ & $11.90(0.41)^{\mathrm{b}}$ & $2.64 * *(\mathrm{TT})$ \\
Food/HH $^{\text {expenditure }}$ & $0.71(0.20)^{\mathrm{a}}$ & $0.63(0.28)^{\mathrm{a}, \mathrm{b}}$ & $0.59(0.28)^{\mathrm{a}, \mathrm{b}}$ & $0.65(0.23)^{\mathrm{a}, \mathrm{b}}$ & $0.52(0.27)^{\mathrm{b}}$ & $0.52(0.18)^{\mathrm{b}}$ & $0.34(0.22)^{\mathrm{c}}$ & $14.68 * * *$ \\
LEA $^{\mathrm{d}}$ & $0.57(0.42)$ & $0.61(1.44)$ & $0.49(0.24)$ & $0.53(0.44)$ & $0.59(0.36)$ & $0.57(0.33)$ & $0.71(0.48)$ & 0.56 \\
FP $^{\mathrm{e}}$ & $0.90(1.35)$ & $1.27(6.46)$ & $0.91(0.91)$ & $0.93(1.18)$ & $1.85(5.59)$ & $1.09(0.54)$ & $2.29(3.74)$ & 1.33 \\
\hline
\end{tabular}

${ }^{a}$ Household Food Insecurity Access Score

${ }^{\mathrm{b}}$ Household Dietary Diversity Score

${ }^{\mathrm{c}}$ Months of Adequate Household Food Provisioning

${ }^{\mathrm{d}}$ Low Energy Availability

${ }^{\mathrm{e}}$ Food Poverty. The results of a Scheffe's posthoc test are reported to show differences between the groups. Within a row, values marked with the same superscript letter are not statistically different. TT indicates that a Tukey HDS test is reported because the Scheffe's test was inconclusive

Table 6 HFIAS scale in relation to the household characteristics

\begin{tabular}{|c|c|c|c|c|c|}
\hline & Food secure & Mildly food insecure & Moderately food insecure & Severely food insecure & F-stat \\
\hline & $14.8 \%$ & $5.8 \%$ & $26.4 \%$ & $53.1 \%$ & \\
\hline & \multicolumn{5}{|c|}{ Mean (standard deviation in brackets) } \\
\hline HFIAS score & $0.57(0.23)^{\mathrm{a}}$ & $2.74(1.20)^{\mathrm{b}}$ & $7.99(3.12)^{\mathrm{c}}$ & $14.64(5.12)^{\mathrm{d}}$ & $362.2 * * *$ \\
\hline Age head & $57.63(14.24)$ & $58.51(15.35)$ & $56.09(15.71)$ & $55.4(16.03)$ & 0.77 \\
\hline Total HH size & $5.61(2.79)^{\mathrm{a}}$ & $5.89(2.49)^{\mathrm{a}, \mathrm{b}}$ & $6.40(2.93)^{\mathrm{a}, \mathrm{b}}$ & $6.95(3.10)^{\mathrm{b}}$ & $5.50 * * *$ \\
\hline Dependency ratio & $0.76(0.20)^{\mathrm{a}}$ & $0.84(0.13)^{\mathrm{b}}$ & $0.83(0.19)^{\mathrm{a}, \mathrm{b}}$ & $0.87(0.16)^{\mathrm{b}}$ & $8.79 * * *$ \\
\hline Non-active/active HH members & $5.14(3.51)$ & $5.85(3.78)$ & $5.20(3.81)$ & $5.06(3.96)$ & 0.46 \\
\hline HH monthly income & $5535.84(6853.31)^{\mathrm{a}}$ & $4357.60(3639.18)^{\mathrm{a}, \mathrm{b}}$ & $2924.01(4420.14)^{\mathrm{b}, \mathrm{c}}$ & $2098.47(2291.42)^{\mathrm{c}}$ & $19.01 * * *$ \\
\hline Monthly income per capita & $1195.08(1715.68)^{\mathrm{a}}$ & $849.88(777.53)^{\mathrm{a}, \mathrm{b}}$ & $692.18(1801.46)^{\mathrm{a}, \mathrm{b}}$ & $332.68(367.17)^{\mathrm{b}}$ & $13.70 * * *$ \\
\hline Livestock index & $0.75(1.03)^{\mathrm{a}, \mathrm{b}, \mathrm{c}}$ & $0.69(1.08)^{\mathrm{a}, \mathrm{b}, \mathrm{c}}$ & $1.02(1.12)^{\mathrm{a}, \mathrm{c}}$ & $0.74(0.91)^{\mathrm{a}, \mathrm{b}}$ & $3.08 * * *$ \\
\hline Livestock units & $3.01(6.90)^{\mathrm{a}, \mathrm{b}, \mathrm{c}}$ & $3.20(8.62)^{\mathrm{a}, \mathrm{b}, \mathrm{c}}$ & $4.47(11.08)^{\mathrm{a}, \mathrm{c}}$ & $1.64(4.03)^{\mathrm{a}, \mathrm{b}}$ & $5.53 * * *$ \\
\hline Crop index & $2.90(3.69)^{\mathrm{a}, \mathrm{b}}$ & $2.14(2.66)^{\mathrm{a}, \mathrm{b}, \mathrm{c}}$ & $1.90(2.34)^{\mathrm{a}, \mathrm{c}}$ & $2.14(2.78)^{\mathrm{a}, \mathrm{b}, \mathrm{c}}$ & $2.44 *$ \\
\hline $\begin{array}{l}\text { Energy from own crop } \\
\text { production }(\mathrm{kcal})\end{array}$ & $568714(1456816)$ & $463376(1446818)$ & $324257(812380)$ & $781885(7690800)$ & 0.24 \\
\hline \multirow[t]{2}{*}{ Land for growing crops (ha) } & $2.04(3.97)^{\mathrm{a}}$ & $0.90(1.61)^{\mathrm{b}}$ & $0.98(2.17)^{\mathrm{a}, \mathrm{b}}$ & $0.88(2.34)^{\mathrm{b}}$ & $4.86^{* * *}$ \\
\hline & & & & & Chi-square \\
\hline Male headed (\%) & 78.40 & 77.10 & 61.10 & 53.50 & $22.50 * * *$ \\
\hline No schooling (\%) & 20.50 & 22.90 & 26.80 & 40.30 & $91.99 * * *$ \\
\hline Junior primary (\%) & 11.40 & 17.10 & 16.60 & 16.90 & \\
\hline Senior primary $(\%)$ & 12.50 & 8.60 & 19.10 & 13.70 & \\
\hline Some secondary (\%) & 17.00 & 14.30 & 17.80 & 17.90 & \\
\hline Completed high school (\%) & 8.00 & 20.00 & 14.60 & 8.30 & \\
\hline $\begin{array}{l}\text { Courses or certificates for } \\
\text { formal training }(\%)\end{array}$ & 10.20 & 8.60 & 1.90 & 1.60 & \\
\hline Diploma or degree $(\%)$ & 19.30 & 8.60 & 3.20 & 1.30 & \\
\hline
\end{tabular}

$* 10 \%$ significance level, $* * 5 \%$ significance level, $* * * 1 \%$ significance level. The results of a Scheffe's posthoc test are reported to show differences between the groups. Within each row, values marked with the same superscript letter are not statistically different 
female-headed households (almost half were female headed) and household heads without schooling were the highest. Only $8.30 \%$ of the household heads had completed high school, although $17.90 \%$ had some secondary education.

Household characteristics in terms of the Rose and Charlton (2002) categories are shown in Table 7. Food secure households had the highest monthly household income, the highest income per capita and the smallest household size. They had a high LEA and FP and had a household head with an average age of 61 years. They had a high dependency ratio and the highest ratio of non-active/active household members, so there were many non-income earners over the total household size and many non-active persons/active persons. They had more livestock units (6.31) and a high energy intake from their own production. Their average land size for growing crops was 1.11 ha and they grew on average 2.74 different crops (crop index). These food secure households had the largest percentage of households headed by males (60\%) who had diverse patterns of education level, many of whom having had no schooling (42\%), but $16 \%$ had completed high school.

When comparing the households that were classified as food insecure based on the categorical indicators mentioned above, it can be seen that households who were food insecure had a low household income, a large household size and were more likely to be headed by women who had a low level of education. These households also usually had a high dependency ratio and were not very active in farming. The indicators also identified the food-secure households as having a small household size, a lower dependency ratio, were more likely to be headed by males and had a better level of education. To achieve food security, they both had to have either high household income and did not actively farm or they had a lower household income but actively farmed.

\section{Comparison of the indicators}

Table 8 gives an overview of the Pearson's correlation coefficients and also shows which correlations are

Table 7 Rose and Charlton categories in relation to household characteristics

\begin{tabular}{|c|c|c|c|c|c|}
\hline & Food insecure & Only low LEA & Only low FP & Food secure & F-stat \\
\hline & $71.1 \%$ & $18.7 \%$ & $1.8 \%$ & $8.3 \%$ & \\
\hline & \multicolumn{5}{|c|}{ Mean (standard deviation in brackets) } \\
\hline LEA & $0.40(0.18)^{\mathrm{a}}$ & $0.64(0.19)^{\mathrm{a}}$ & $2.39(3.91)^{\mathrm{b}}$ & $1.45(0.55)^{\mathrm{c}}$ & $91.97 * * *$ \\
\hline FP & $0.51(0.24)^{\mathrm{a}}$ & $2.98(7.44)^{\mathrm{b}}$ & $0.70(0.24)^{\mathrm{a}}$ & $2.45(1.57)^{\mathrm{a}, \mathrm{b}}$ & $19.60 * * *$ \\
\hline Age head & $55.41(15.53)$ & $55.72(14.94)$ & $64.55(8.68)$ & $60.88(18.24)$ & $2.95 * *(\mathrm{NC})$ \\
\hline HH size & $7.15(2.91)^{\mathrm{a}}$ & $5.71(2.64)^{\mathrm{a}}$ & $5.91(3.51)^{\mathrm{a}}$ & $3.36(1.81)^{\mathrm{b}}$ & $31.82 * * *$ \\
\hline Dependency ratio & $0.85(0.17)^{\mathrm{a}, \mathrm{b}}$ & $0.79(0.18)^{\mathrm{a}}$ & $0.91(0.12)^{\mathrm{b}}$ & $0.87(0.23)^{\mathrm{a}, \mathrm{b}}$ & $4.64 * *$ \\
\hline Non-active/active HH members & $4.61(3.54)^{\mathrm{a}}$ & $5.87(3.95)^{\mathrm{z}}$ & $6.06(4.62)^{\mathrm{a}, \mathrm{b}}$ & $8.76(4.27)^{\mathrm{b}}$ & $17.38 * * *$ \\
\hline Monthly income of the $\mathrm{HH}$ & $2191.67^{\mathrm{a}}(2258.92)$ & $4839.48^{\mathrm{b}}(4789.76)$ & $2240.00^{\mathrm{a}}(1808.55)$ & $5373.22^{\mathrm{b}}(9545.71)$ & $20.32 * * *$ \\
\hline Monthly income per capita & $334^{\mathrm{a}}(370)$ & $1073^{\mathrm{b}, \mathrm{c}}(1771)$ & $364^{\mathrm{a}, \mathrm{b}}(191)$ & $1673^{\mathrm{c}}(2734)$ & $29.06^{* * *}$ \\
\hline Livestock index & $0.77(0.97)$ & $0.96(1.13)$ & $0.82(0.87)$ & $0.82(0.98)$ & 0.96 \\
\hline Livestock units & $1.82(5.36)^{\mathrm{a}}$ & $4.40(8.42)^{\mathrm{b}}$ & $1.96(4.46)^{\mathrm{a}, \mathrm{b}}$ & $6.31(14.54)^{\mathrm{b}}$ & $8.49 * * *(\mathrm{TT})$ \\
\hline Crop index & $1.88(2.58)^{\mathrm{a}}$ & $3.01(3.37)^{\mathrm{b}}$ & $3.45(2.77)^{\mathrm{a}, \mathrm{b}}$ & $2.74(3.09)^{\mathrm{a}, \mathrm{b}}$ & $6.40^{* * *}(\mathrm{TT})$ \\
\hline Own production energy (kcal) & $21363^{\mathrm{a}}(65086)$ & $36733^{\mathrm{a}}(77366)$ & $1197705^{\mathrm{b}}(3369933)$ & $82443^{\mathrm{a}}(198248)$ & $25.07 * * *$ \\
\hline Land for growing crops (ha) & $0.82(2.00)^{\mathrm{a}}$ & $2.00(3.75)^{\mathrm{b}}$ & $1.46(2.01)^{\mathrm{a}, \mathrm{b}}$ & $1.11(3.51)^{\mathrm{a}, \mathrm{b}}$ & $\begin{array}{l}6.41^{* * *}(\mathrm{TT}) \\
\text { Chi-square }\end{array}$ \\
\hline Male headed (\%) & 57.51 & 73.21 & 45.45 & 60.00 & $10.07 * *$ \\
\hline No schooling (\%) & 34.27 & 20.54 & 36.36 & 42.00 & $64.94 * * *$ \\
\hline Junior primary (\%) & 18.08 & 8.93 & 36.36 & 8.00 & \\
\hline Senior primary $(\%)$ & 14.79 & 16.07 & 18.18 & 8.00 & \\
\hline Some secondary (\%) & 18.78 & 17.86 & 0.00 & 8.00 & \\
\hline Completed high school (\%) & 8.69 & 15.18 & 9.00 & 16.00 & \\
\hline $\begin{array}{l}\text { Courses or certificates for formal } \\
\text { training }(\%)\end{array}$ & 2.11 & 7.14 & 0.00 & 6.00 & \\
\hline Diploma or degree $(\%)$ & 2.11 & 14.29 & 0.00 & 8.00 & \\
\hline
\end{tabular}

$* 10 \%$ significance level, $* * 5 \%$ significance level, $* * * 1 \%$ significance level. The results of a Scheffe's posthoc test are reported to show differences between the groups. Within a row, values marked with the same superscript letter are not statistically different. TT indicates that a Tukey HDS test is reported because the Scheffe's test was inconclusive, NC indicates that the Scheffe's and Tukey HDS tests were inconclusive 
Table 8 Pearson's correlation coefficients for the continuous variables

\begin{tabular}{lccccc}
\hline & HFIAS $^{\mathrm{a}}$ & HDDS $^{\mathrm{b}}$ & MAHFP $^{\mathrm{c}}$ & Food/HH expenditure & LEA $^{\mathrm{d}}$ \\
\hline HFIAS & 1.00 & $-0.35^{* * *}$ & $-0.48^{* * *}$ & $0.23^{* * *}$ & $-0.12^{* * *}$ \\
HDDS & $-0.35^{* * *}$ & 1.00 & $0.14^{* * *}$ & $-0.14^{* * *}$ & $-0.15^{* * *}$ \\
MAHFP & $-0.48^{* * *}$ & $0.14^{* * *}$ & 1.00 & -0.02 & $0.17^{* * *}$ \\
Food/HH expenditure & $0.23^{* * *}$ & $-0.14^{* * *}$ & -0.02 & 1.00 & $0.12^{* * *}$ \\
LEA & $-0.12^{* * *}$ & $0.17^{* * *}$ & $0.12^{* * *}$ & -0.02 & -0.06 \\
FP & $-0.15^{* * *}$ & $0.13^{* * *}$ & 0.06 & $-0.20^{* * *}$ & $-0.20^{* * *}$ \\
\hline
\end{tabular}

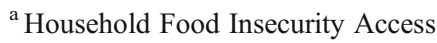

${ }^{\mathrm{b}}$ Household Dietary Diversity Score

${ }^{\mathrm{c}}$ Months of Adequate Household Food Provisioning

${ }^{\mathrm{d}}$ Low Energy Availability

${ }^{\mathrm{e}}$ Food Poverty

$* 10 \%$ significance level, $* * 5 \%$ significance level, $* * * 1 \%$ significance level

significant and at what level. The HFIAS score is negatively correlated with HDDS, MAHFP, LEA and FP. This is evident as a higher HFIAS score means the household is more food insecure, while higher HDDS, MAHFP, LEA and FP scores indicate better food security status. With Food/HH expenditure, the HFIAS score shows a positive correlation since the higher food/HH expenditure the more food insecure a household is. All correlations between the HFIAS score and the other indicators were significant at the 0.01 level.

The HDDS score showed a positive correlation with MAHFP, LEA and FP and a negative correlation with HFIAS and food/HH expenditure. This is again to be expected as HDDS, MAHFP, LEA and FP increase as the food security status increases and food/HH expenditure and HFIAS decrease as the food security status increases.

MAHFP showed a positive correlation with HDDS, LEA and FP and a negative correlation with HFIAS and food/HH expenditure. Here not all correlations were significant, MAHFP only showed significant correlation (at 0.01 level) with HFIAS, HDDS and LEA. This could be explained by the fact that MAHFP measures the number of months a household is able to provide itself with enough food while food/HH expenditure and FP focuses only at the monetary value of food (share of food expenditure). They are a household's expenditure on food plus the monetary value of their livestock and crops and are higher than the price of an adequate food basket. It is also because MAHFP is a perceptive measure, while the other two are more objective measures. Another point to mention is that MAHFP measures food security over the whole year, while the time scale of the other indicators is 1 month.

LEA showed positive correlations with HDDS, MAHFP and FP and negative correlations with HFIAS and food/HH expenditure. These correlations were significant at the 0.01 level for HFIAS, HDDS and MAHFP, and significant at the 0.05 level for FP and not significant for food/HH expenditure. The latter can be explained by the fact that LEA measures food security purely in the form of energy intake while food/HH expenditure focuses purely on food expenditure. LEA showed the best correlation with HDDS and had a similar correlation with HFIAS and MAHFP, which are both perceptive measures of food security. However, it should be noted that all significant correlation coefficients were lower than 0.5 or $50 \%$, which indicates that the variables are related but that the strength of the correlations is weak.

Cross tabulation with a chi-square test for categorical variables

Table 9 shows the classification of households into food (in)secure categories according to the Rose and Charlton and the HFIAS methods respectively. The data show that 262 households were categorized as severely food insecure by HFIAS and as food insecure by Rose and Charlton: these represented $62 \%$ and $82 \%$ of the total households classified as least food secure by these methods respectively. On the other hand, only 28 of the households that were categorized as food insecure by Rose and Charlton were categorized as food secure by HFIAS. Hence, these two indicators categorize households in a similar manner, even though they use different methods.

Determinants of food security

The determinants of food insecurity were checked using a logistic regression which calculates the changes in the 
Table 9 A comparison between the classifications from the HFIAS categories and the Rose and Charlton categories

\begin{tabular}{|c|c|c|c|c|c|c|c|c|}
\hline & & \multicolumn{4}{|c|}{ HFIAS categories } & \multirow[b]{2}{*}{ Total } & \multirow[b]{2}{*}{$\begin{array}{l}\text { Pearson's } \\
\text { Chi-square }\end{array}$} & \multirow[b]{2}{*}{ Pearson's R } \\
\hline & & $\begin{array}{l}\text { Food } \\
\text { secure }\end{array}$ & $\begin{array}{l}\text { Mildly food } \\
\text { insecure }\end{array}$ & $\begin{array}{l}\text { Moderately } \\
\text { food insecure }\end{array}$ & $\begin{array}{l}\text { Severely food } \\
\text { insecure }\end{array}$ & & & \\
\hline \multirow[t]{5}{*}{ Rose and Charlton } & Food insecure & 28 & 18 & 118 & 262 & 426 & \multirow[t]{5}{*}{$108.29 *$} & \multirow[t]{5}{*}{$-0.33^{*}$} \\
\hline & Only low LEA & 41 & 8 & 29 & 34 & 112 & & \\
\hline & Only low FP & 1 & 1 & 1 & 8 & 11 & & \\
\hline & Food secure & 18 & 8 & 10 & 14 & 50 & & \\
\hline & Total & 88 & 35 & 158 & 318 & 599 & & \\
\hline
\end{tabular}

probability of being food insecure (dependent variable food insecure $=1$, food secure $=0$ ) brought about by a unit change in the independent variable. The model was calculated in SPSS. More details of the model specifications can be obtained from the authors upon request.

The food security categorisation is based on the HFIAS categories. The food insecure group are the households categorised as severely food insecure by the HFIAP method.
As mentioned, food insecurity is a multidimensional livelihood outcome, as is poverty, with multiple determinants. For each of the above pointers, the importance of a set of appropriate determinants at household level, including household characteristics, household assets and location indicators is estimated. Table 10 shows the results. We report the coefficients (B) and the changes in odds $(\operatorname{Exp}(B))$, and show three different model specifications.

Table 10 Regression analysis (dependent variable Food insecurity=1; food secure $=0, n=599$ )

\begin{tabular}{|c|c|c|c|c|c|c|}
\hline & \multicolumn{2}{|l|}{ Model 1} & \multicolumn{2}{|l|}{ Model 2} & \multicolumn{2}{|l|}{ Model 3} \\
\hline & Coefficient & $\begin{array}{l}\text { Change } \\
\text { in odds }\end{array}$ & Coefficient & $\begin{array}{l}\text { Change } \\
\text { in odds }\end{array}$ & Coefficient & $\begin{array}{l}\text { Change } \\
\text { in odds }\end{array}$ \\
\hline Constant & $-2.802 * * *$ & 0.061 & $-1.990 * * *$ & 0.137 & $-2.358 * * *$ & 0.095 \\
\hline Age household head & $-0.022 * *$ & 0.978 & $-0.025 * * *$ & 0.976 & $-0.016^{* * *}$ & 0.984 \\
\hline Household size & $0.118^{* * *}$ & 1.125 & $0.120 * * *$ & 1.127 & $0.116^{* * *}$ & 1.123 \\
\hline Dependency ratio & $1.840 * * *$ & 6.298 & $1.395 * *$ & 4.036 & $1.406 * * *$ & 4.080 \\
\hline Gender household head (1: male headed, 2: female) & 0.255 & 1.290 & 0.225 & 1.252 & 0.213 & 1.238 \\
\hline Total land used for crops (ha) & -0.011 & 0.989 & -0.017 & 0.983 & -0.007 & 0.993 \\
\hline Crop index (number of corps grown) & -0.017 & 0.984 & -0.002 & 0.998 & -0.001 & 0.999 \\
\hline No schooling (1:yes) & $1.230 * * *$ & 3.422 & $1.061 * * *$ & 2.890 & $1.002 * * *$ & 2.724 \\
\hline Primary only (1: yes) & $0.420 *$ & 1.522 & 0.263 & 1.301 & 0.182 & 1.199 \\
\hline Remittance as main income (1: yes) & $-1.103 * *$ & 0.332 & & & & \\
\hline Pensions as main income (1: yes) & -0.354 & 0.702 & & & -0.286 & 0.751 \\
\hline Grants as main income (1:yes) & & & & & 0.227 & 1.255 \\
\hline Monthly income (R) & & & $0.000 * * *$ & 1.000 & $0.000 * * *$ & 1.000 \\
\hline Capricorn district (Sekukhune) ${ }^{\mathrm{a}}$ & $1.490 * * *$ & 4.435 & $1.392 * * *$ & 4.023 & $1.439 * * *$ & 4.219 \\
\hline Mopani district & $1.520 * * *$ & 4.573 & $1.262 * * *$ & 3.537 & $1.283 * * *$ & 3.609 \\
\hline Vhembe district & $1.197 * * *$ & 3.311 & $1.213 * * *$ & 3.364 & $1.247 * * *$ & 3.480 \\
\hline Waterberg district & $1.829 * * *$ & 6.231 & $1.639 * * *$ & 5.152 & $1.686^{* * *}$ & 5.400 \\
\hline $\begin{array}{l}\text { Model statistics } \\
\% \text { correctly classified }\end{array}$ & 67.1 & & 68.8 & & 69.3 & \\
\hline-2 Log likelihood & 693.916 & & 595.314 & & 689.207 & \\
\hline Cox§Snell $\mathrm{R}^{2}$ & 0.182 & & 0.185 & & 0.188 & \\
\hline Nagelkerke $\mathrm{R}^{2}$ & 0.243 & & 0.247 & & 0.251 & \\
\hline
\end{tabular}

${ }^{\text {a }}$ Sekhukhune is the reference point

$* 10 \%$ significance level, $* * 5 \%$ significance level, $* * * 1 \%$ significance level 
The results show that human capital, household income and location seem to be the most important determinants of food security, while food production and access to land do not appear to be determinants of food security in this sample as their coefficients are not significantly different from zero. Households that produce or sell crops or farm with livestock do not have a higher probability of being food secure.

Smaller households with older and more educated household heads seem to have lower odds to be food insecure. Obviously, a higher monthly income leads to higher food security levels and when a household has remittances as its most important income source, its probability of being food secure is higher. The model confirms that households in Sekhukhune (which was used as the reference point for Capricorn district) are better off compared to households living in the other districts.

\section{Discussion}

This research aimed at assessing the situation of rural households in the Limpopo province. Qualitative and quantitative data were gathered over five districts in Limpopo province during August 2011 from among 599 households. Information related to the household composition, food consumption, food production, household income, and access to resources, was gathered. From these data, specific measures of food security and poverty were derived and used for analysis.

Based on the subjective declaration of the households and using the HFIAS categories, $53 \%$ of the households were severely food insecure. The Mopani district seemed to have the highest poverty rates $(50 \%)$, while the Vhembe district presented the lowest poverty rates (19\%). The average monthly household income in the area was R3055 (SD: R 4154) and the most important sources were grants, formal income and farm income. Half of the households were involved in agriculture, with poultry, maize, mango and cattle the most important activities.

Secondly, the expected links, e.g. the relationship between income and food security status, and between education and food security status, to name just two, are clearly present, which indicates that the results are internally consistent.

Thirdly, the tendencies of very high food insecurity levels are found consistently in the data. Even if these results were exaggerated and negatively biased, the food insecurity situation remains problematic. The analysis showed how the most important determinants of food security at the household level can be grouped into i) human capital, entailing mainly education and age of the household head, household size and dependency ratio, ii) household income, and iii) location. Household food production does not seem to contribute to a higher food security status. This entails that currently households who might have weaker access to external income are not able to compensate by producing food for subsistence purposes.

From these findings it is clear that the promotion of rural education can contribute to improving food security levels to a large extent, as education is significantly correlated with food security. A second important policy arena is related to the labour market. Policies should be focused on creating an open, viable and dynamic rural labour market with sustainable employment opportunities.

Acknowledgments The research team wishes to thank the National Agricultural Marketing Council (NAMC) for funding this research. The assistance of the Stellenbosch Institute for Advanced Studies (STIAS) towards the research is also acknowledged. The authors declare that they have no conflict of interest.

Open Access This article is distributed under the terms of the Creative Commons Attribution License which permits any use, distribution, and reproduction in any medium, provided the original author(s) and the source are credited.

\section{References}

Aliber, M. (2009). Exploring Statistics South Africa's national household surveys as sources of information about household-level food security. Agrekon, 48(4), 384-409.

Altman, M., Hart, T. G. B., \& Jacobs, P. T. (2009). Household food security status in South Africa. Agrekon, 48(4), 345361.

Baiphethi, M. (2009). The contribution of subsistence farming to food security in South Africa. Pretoria: Centre for Poverty Employment and Growth, Human Sciences Research Council.

Ballantine, N., Rousseau, G. G., \& Venter, D. J. L. (2008). Purchasing behaviour as a determinant of food insecurity. In M. Baiphethi (Ed.), The contribution of subsistence farming to food security in South Africa. Pretoria: Centre for Poverty Employment and Growth, Human Sciences Research Council.

Coates, J., Wilde, P. E., Webb, P., Rogers, B. L., \& Houser, R. F. (2006). Comparison of a qualitative and quantitative approach to developing a household food insecurity scale for Bangladesh. Journal of Nutrition, 136(5), 1420S-1430S.

Coates, J., Swindale, A., \& Bilinsk, P. (2007). Household Food Insecurity Access Scale (HFIAS) for measurement of food access: Indicator guide, version 3. Washington: Food and Nutrition Technical Assistance Project, Academy for Educational Development.

Deitchler, M., Ballard, T., Swindale A., Coates J. (2010). Validation of a measure of household hunger for cross cultural use. US State 
Department Third Annual Conference on program evaluation: New paradigms for evaluating diplomacy in the 21 st Century. June 8-9.

DGRV (2003). Burial societies in South Africa: History, function and scope. Deutscher Genossenschafts-und Raiffeisenverband e.V. Working Paper Series No 2 - September 2003.

EIU. (2012). The global food security index, 2012. London: The Economist Intelligence Unit.

Faber, M., Schwabe, C., \& Drimie, S. (2009). Dietary diversity in relation to other household food security indicators. International Journal of Food Safety, Nutrition and Public Health, 2(1), 1-15.

FAO. (2008). Deriving food security information from national household budget surveys: Experiences, achievements, challenges. Rome: Food and Agricultural Organization of the United Nations.

Frongillo, E., \& Nanama, S. (2006). Development and validation of an experience-based measure of household food insecurity within and across seasons in Northern Burkina Faso. Journal of Nutrition, 136(5), 1409S-1419S.

Governement of South Africa (2010). Outcome 7: vibrant, equitable and sustainable rural communities and food security for all. Draft 10 May 2010. Retrieved from http://www.info.gov.za/view/ DownloadFileAction?id=134061 on 12/09/2012

Gumede, V. (2010). Poverty, inequality and human development in a post-Apartheid South Africa. Conference paper presented at Overcoming inequality and structural poverty in South Africa: Towards inclusive growth and development, Johannesburg, 20-22 September 2010. Institute for poverty, land and agrarian studies

Hart, T. (2009). The status of household food security targets in South Africa. Agrekon, 48(4), 362-383.

Hendriks, S. L. (2005). The challenges facing empirical estimation of food (in)security in South Africa. Development Southern Africa, 22(1), 103-123.

IFSS. (2002). Integrated food security strategy. Pretoria: National Department of Agriculture Policy Document.

Jacobs, P. T. (2009). The status of household food security targets in South Africa. Agrekon, 48(4), 410-433.

Kirkland, T., Kemp, R., Hunter, L., Twine, W. (2011). Toward improved understand of food security: a methodological examination based in rural South Africa. University of Colorado Boulder, Institute of Behavioral Science.

Labadarios, D., Davids, Y. D., Mchiza, Z., \& Weir-Smith, G. (2009). The assessment of food insecurity in South Africa. Pretoria: Centre for Poverty, Employment and Growth, Human Sciences Research Council.

Labadarios, D., Steyn, N. P., \& Nel, J. (2011). How diverse is the diet of adult South Africans? Nutrition Journal, 10, 33.

Leroy J.L.J.P., van Rooyen J., D'Haese L. and de Winter A. (2001). A quantitative determination of the food security status of rural farming households in the Northern Province of South Africa, Development Southern Africa. 18(1).

Melgar-Quinonez, H., et al. (2006). Household food insecurity and food expenditure in Bolivia, Burkina Faso, and the Philippines. Journal of Nutrition, 136(5), 1431S-1437S.

Modi, M., Modi, A. T., \& Hendriks, S. (2006). Potential role for wild vegetables in household food security: a preliminary case study in Kwazulu-Natal, South Africa. African Journal of Food, Agriculture, Nutrition and Development, 6(1), 13.

NAMC. (2011). Food prince monitor: August 2001. Pretoria: National Agricultural Marketing Council (NAMC).
NFCS. (2005). National food consumption survey. Pretoria: Statistics South Africa.

NFCS-FB-I. (2008). Executive summary of the National Food Consumption Survey Fortification Baseline, South Africa. African Journal of Clinical Nutrition, 21((3)(Suppl 2)), 245-300.

Oketch, J., Paterson, M., Maunder, W., \& Rollins, N. (2011). Too little, too late: comparison of nutritional status and quality of life of nutrition care and support recipient and non-recipients among HIV-positive adults in KwaZulu-Natal, South Africa. Health Policy, 99(3), 267-276.

Rose, D., \& Charlton, K. E. (2002). Quantitative indicators from a food expenditure survey can be used to target the food insecure in South Africa. The Journal of Nutrition, 132, $3235-3242$.

Rule, S., Aird, R., Drimie, S., Faber, M., Germishuyse, T., et al. (2005). Report on survey in Sekhukhune to pilot the development of a food insecurity and vulnerability modelling system (FIVIMS) for South Africa. Pretoria: Human Sciences Research Council for the FIVIMS Consortium.

SSA. (2008). Income and expenditure of households 2005/2006: Analysis of results. Pretoria: Statistics South Africa.

Swindale, A., \& Bilinsky, P. (2006). Development of a universally applicable household food insecurity measurement tool: process, current status, and outstanding issues. Journal of Nutrition, 136(5), 1449S-1452S.

Swindale, A., \& Bilinsky, P., (2007). Months of Adequate Household Food Provisioning (MAHFP) for measurement of household food access: indicator guide, FANTA.

Taylor, T., Kidman, R., Thurman, T. (2011). Household resources and access to social grants among orphans and vulnerable children in KwaZulu-Natal, South Africa. Tulane University School of Public Health and Tropical Medicine.

Webb, P., et al. (2006). Measuring household food insecurity: why it's so important and yet so difficult to do. Journal of Nutrition, 136(5), 1404S-1408S.

Zita, M.L., (2012). Zero hunger programme for the Republic of South Africa. DAFF, 15 May 2012.

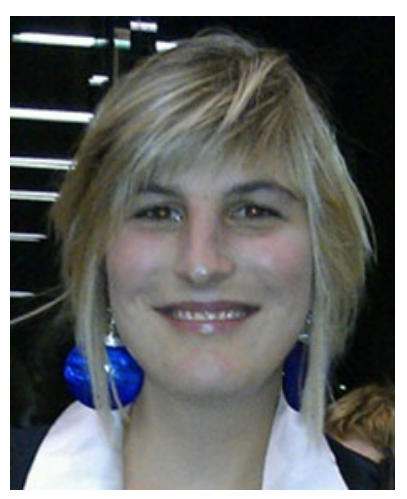

Nathalie De Cock completed the MSc in Bioscience Engineering in Food Science and Nutrition in 2011 at Ghent University. In addition, she obtained the MSc in Nutrition and Rural Development in 2012 , with a main subject in human nutrition. In her masters dissertation "A comparative overview of commonly used food security indicators, case study in the Limpopo province, South Africa" she compared the most frequently used food security indicators using data collected in the province of Limpopo. From January 2013 she started working as a PhD student at Ghent University on the REWARD project in which a new method using games and rewards will be tested to modify the eating habits of young children and adolescents. 


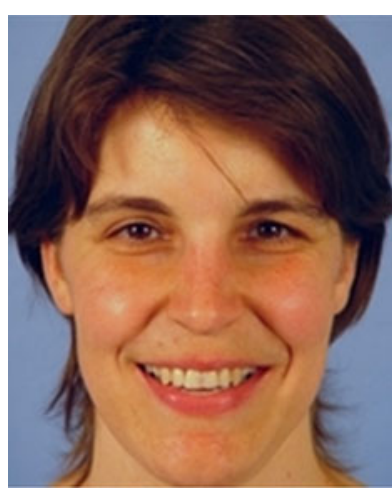

Marijke D'Haese is with the Department of Agricultural Economics at Ghent University, and holds a PhD in applied biological sciences from that University. She has been involved in studies on South African rural development since 1996 with a research focus on agricultural development, food security and rural poverty.

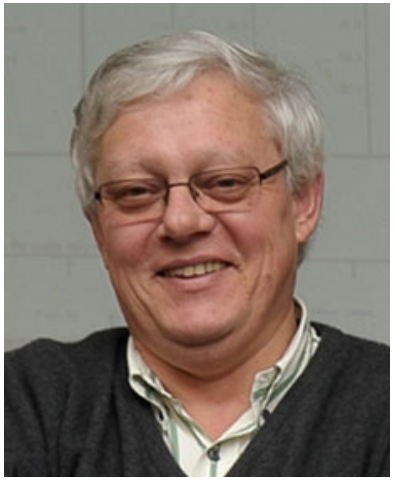

Nick Vink is Chair of the Department of Agricultural Economics at the University of Stellenbosch. He is currently President and an Honorary Fellow of the African Association of Agricultural Economists, a Fellow of the American Association of Wine Economists and an Honorary Life Member of the International Association of Agricultural Economists. He served as President of the Agricultural Economics Association of South Africa in 1991-1993. He was Editor of Development Southern Africa for more than 10 years, and of Agrekon, the Journal of AEASA, from 2002 to 2010.

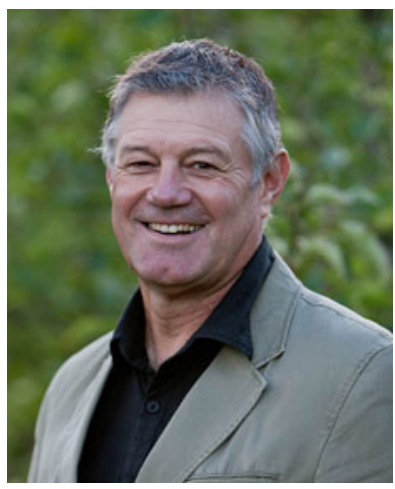

Johan van Rooyen is currently the Director of the "Standard Bank Centre for Agri-leadership \& Mentorship Development" and Professor in Agricultural Economics at Stellenbosch University. He teaches agri-business strategy, agricultural and rural development and business cases at the Universities of Stellenbosch, Free State, Pretoria and Ghent in Belgium. He has published widely, and has presented academic papers at conferences around the globe. He is a recipient of the F.R. Tomlinson Medal, and holds a D.Sc in Agricultural Economics from the University of Pretoria and a management certificate from the IMD in Switzerland.

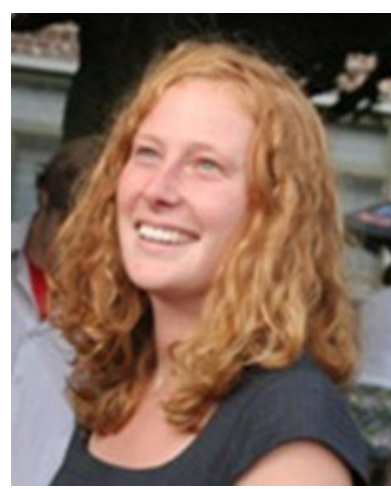

Lotte Staelens is an Academic Assistant in the Department of Agricultural Economics at Ghent University, Belgium and is working as a $\mathrm{PhD}$ student on the Ethiopian flower industry. She completed her Master's degree in nutrition and rural development at that University with a dissertation entitled: "Changing livelihoods in Cajamarca, Peru: impact study of the Yanacocha mine using the livelihood framework." Her research focuses on agricultural development, working conditions and CSR practices.

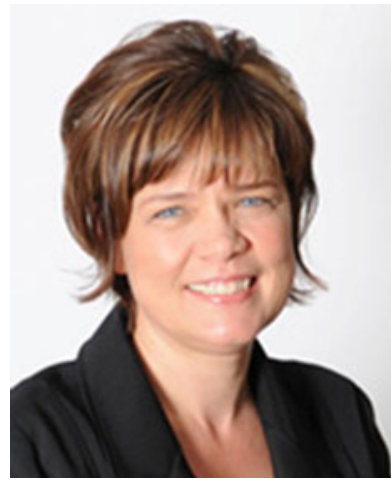

Hettie Schönfeldt is a Professor Extraordinaire at the University of Pretoria's School of Agricultural and Food Sciences and an Associate of the Institute of Food, Nutrition and Well-being in the Faculty of Natural and Agricultural Sciences. She is the Administrator of the Red Meat Research and Development South Africa Programme.

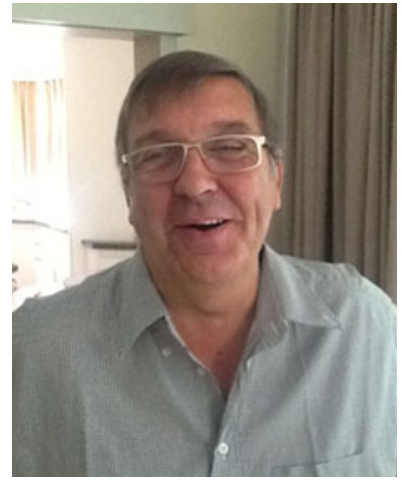

Luc D'Haese is Emeritus Professor of the Department of Bio Science Engineering of the University of Antwerp and the Department of Agricultural Economics at the University of Ghent. He is currently Extra Ordinary Professor of the University of Stellenbosch and the University of Pretoria. He served as CEO of the Belgian Technical Cooperation and he was managing for more than 15 years the International Course in Food and Nutrition at the University of Ghent. He was from 1977 to 1992 Professor at University of Burundi. He is associated member of the Belgian Royal Academy of Science. 